\title{
Comparative Geochemistry of Seguela kimberlites, South Africa Group II kimberlites and other worldwide kimberlites
}

\author{
M.E. Allialy ${ }^{1}$, S.C. Djro ${ }^{1}$, C. Yacouba ${ }^{1}$, A.N. Kouamelan ${ }^{1}$, K.B. Pothin ${ }^{1}$, D.B. Yao ${ }^{2}$, and \\ R. Yobou ${ }^{3}$ \\ (1) UFR-STRM University of Cocody-Abidjan 22 BP 582 Abidjan 22, Ivory Coast (2) Geology Department of Ivory \\ Coast, (3) Cluff-Gold Department (W.A), Ivory Coast \\ (allialy@hotmail.fr)
}

\section{Introduction}

Kimberlites were first discovered in West Africa about forty year ago (Grantham and Allen, 1960). Bardet and Vachette (1966) recognize several episodes of kimberlites emplacement in West Africa, but lateMesozoic kimberlites are the most extensive and several fields are known from Guinea, Sierra Leone, Liberia and Mali on the West Africa craton (Fig.1). There are however, few published petrological and geochemical invetigations of West African kimberlites, and little has been published. An important aspect of these investigations is to compare these compositions with published major and trace element analysis of kimberlites from other localities (central Africa, south Africa, northwest Australia).

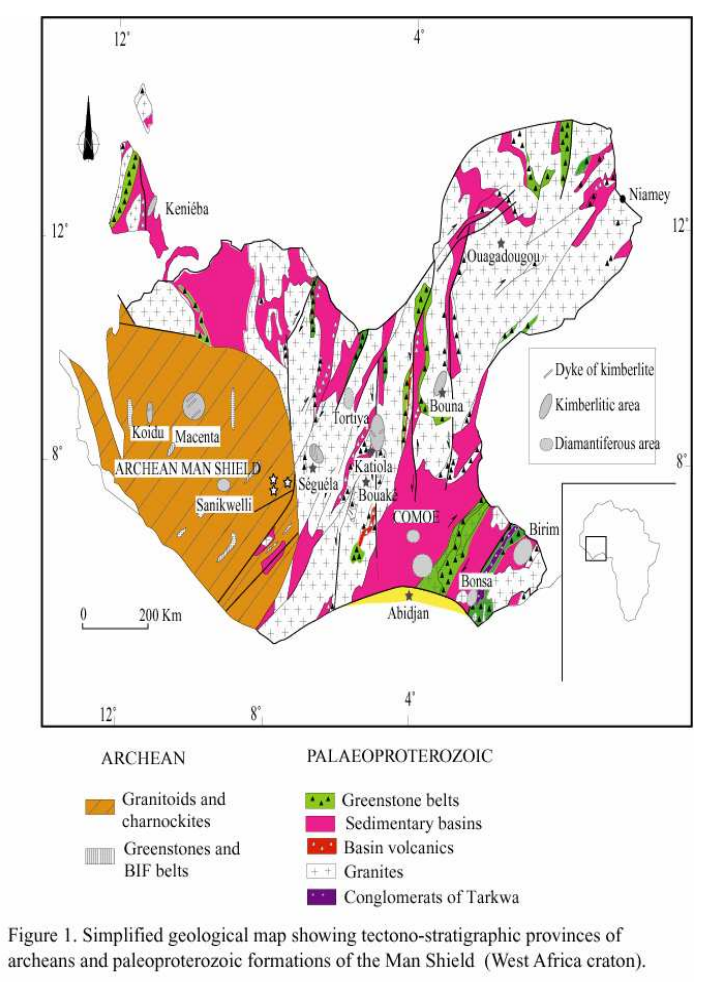

\section{Geological setting}

Seguela diamond-bearing field is located in the centralwestern part of Ivory Coast, $30 \mathrm{~km}$ north of Seguela.
Diamonds, averaging $0.3 \mathrm{ct}$, are disseminated into eluvia, colluvia and alluvia and originated from the two main kimberlitic dykes of Bobi and Toubabouko (Fig.2). The dykes, trending N170, crosscut the granitic plutons and amphibolites of the Palaeoproterozoic Birimian formations of the West-African craton. Seguela granite is dated at 2.091 Ma (Allialy, 2006). The dyke of Bobi is $2.5 \mathrm{~km}$ long and 25 to $50 \mathrm{~cm}$ wide. Length of the dyke of Toubabouko reaches $4.5 \mathrm{~km}$ and its wideness, $80 \mathrm{~cm}$ to $1 \mathrm{~m}$. In the northern part of this dyke, we discovered a typical kimberlitic diatreme with its complete lithostructural features $\left(\mathrm{N}^{\circ} 15,22\right.$ ', W $6^{\circ} 37^{\prime} 57^{\prime \prime}$ ).

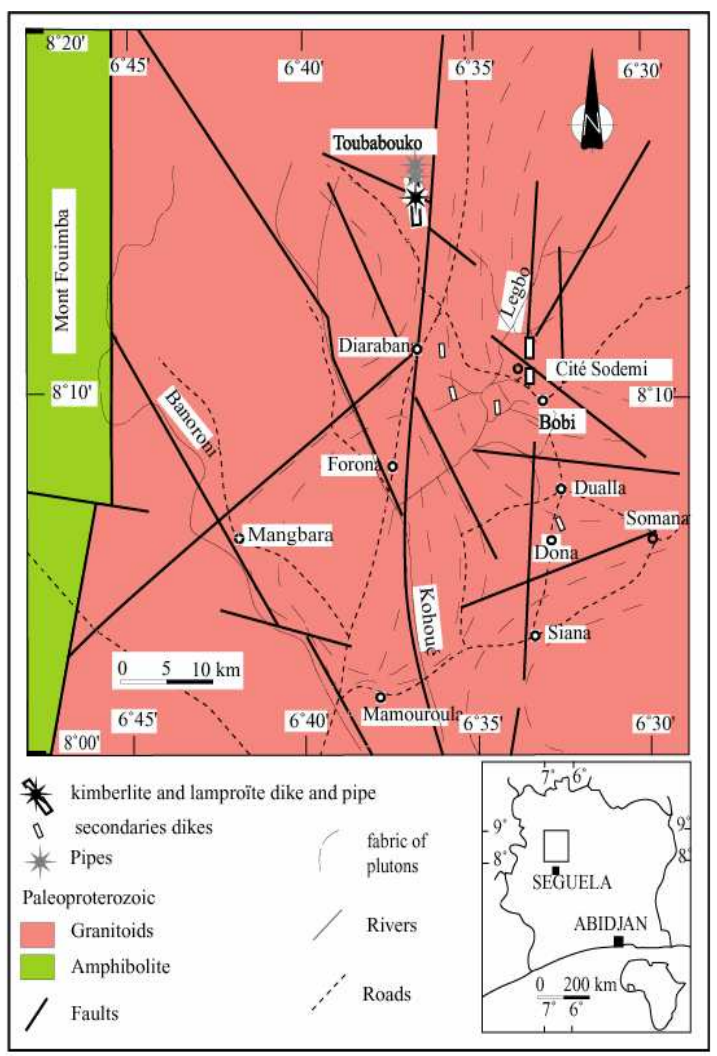

Figure 2: Simplified geological map of Seguela area (Ivory coast) 


\section{Samples descriptions}

Three types of samples are known from Seguela: sensu stricto kimberlite, kimberlite enriched in olivine nodules, and micaceous kimberlite or lamproite According to Clement (1982) Contamination Index (C.I. $\left.=\mathrm{SiO}_{2}+\mathrm{Al}_{2} \mathrm{O}_{3}+\mathrm{Na}_{2} \mathrm{O}\right) /\left(2 \mathrm{~K}_{2} \mathrm{O}+\mathrm{MgO}\right.$. $)$ for kimberlites. Seguela diamond-bearing kimberlites are contaminated by crustal materials because they have C.I.'s (1.99 to 2.62 ) up to 1.5 or more.

\section{Major element geochemistry}

The major element contents are strongly modified by talcification process and alteration.

The Seguela dikes and pipe samples have $\mathrm{TiO}_{2}(1-$ 4) and $\mathrm{K}_{2} \mathrm{O}(0.2-1.1)$ contents similar to those of nonmicaceous kimberlites. In contrast $\mathrm{P}_{2} \mathrm{O}_{5}(0.5-2)$ contents in the Seguela kimberlites are generally higher than southern African, Sierra Leone and Congo Democratique kimberlites. $\mathrm{Al}_{2} \mathrm{O}_{3}$ (1.6-7) and $\mathrm{TiO}_{2}$ contents are similar to the South Africa micaceous kimberlite.

\section{Trace element geochemistry}

Compatible traces elements

Seguela kimberlites are characterized by high Ni (679$1355 \mathrm{ppm})$ and $\mathrm{Cr}$ (525-1399 ppm) contents. Ni/MgO ratios (33-63) are similar to average Group II kimberlites (Mitchell, 1986).

\section{Incompatible traces elements}

The Seguela kimberlite have 300-1400 times chondritic abundance for La (Fig.3) which is generally higher than Group I but similar to Group II kimberlites (Allialy, 2006). The Seguela kimberlites all have steep REE patterns with $(\mathrm{La} / \mathrm{Yb})_{\mathrm{n}}=(119-366)$, as is typical of kimberlites worldwide (Mitchell, 1986). One feature of the REE patterns for the Seguela rocks is the apparent depletion of middle REE (Eu to Ho) that gives the patterns a downward concave shape. Comparative element abundance plots normalized against primitive mantle values (Fig.4) show marked large-ion lithophile element (LILE) and LREE enrichments (> 100 time primitive mantle abundance) with pronounced positive $\mathrm{Nb}, \mathrm{Nd}$, and $\mathrm{Sm}$ anomalies, and negative $\mathrm{K}, \mathrm{Sr}, \mathrm{P}, \mathrm{Hf}$, and $\mathrm{Zr}$ anomalies. These are all features previously documented for kimberlites (Sun and McDonough, 1989). The element abundance patterns indicate that Seguela kimberlites have closest affinity with southern Africa Group II kimberlites and olivine lamproites.

For the trace elements that behave incompatibility during mantle partial melting, those in the Seguela kimberlites show distinctive characteristics compared to intraplate basaltic rocks (e.g., non-DUPAL OIB) and most other kimberlites, with the exception of the Kundelungu kimberlites (Fieremans et al., 1984). For example the Seguela kimberlites have not noticeably elevated $\mathrm{Nb} / \mathrm{Zr}(0.19-0.30)$ ratios compared with Group I kimberlites but similar to Group II and olivine lamproites. Similary, The $\mathrm{P}_{2} \mathrm{O}_{5} / \mathrm{Ce} \quad$ (22-37) characteristics of these kimberlites are distinctive. Seguela kimberlites have lower $\mathrm{P}_{2} \mathrm{O}_{5} / \mathrm{Ce}$ ratios compared to Atlantic Ocean OIB $(\approx 60-100)$, Group I and Koidu calcite kimberlite but similar to Group II kimberlites, and olivine lamproites. They also have $\mathrm{Nb} / \mathrm{La}(0.77-1.09)$ characteristics similar to Group II kimberlites, olivine lamproites and DUPAL OIB. But like Kundelungu, Group II kimberlites, and olivine lamproites, the Seguela kimberlites have elevated $\mathrm{Ce} / \mathrm{Sr}$ ratios $(0.22-0.54)$. Low $\mathrm{Nb} / \mathrm{La}$ is coupled with elevated $\mathrm{Ce} / \mathrm{Sr}$ in These kimberlites like group II kimberlites and olivine lamproites consistent with a recycled sediment component in mantle source region of these rocks.

The presence of higher content of $\mathrm{Zr}(<719 \mathrm{ppm})$, and $\mathrm{MgO}$ contents in spinel $(<15)$ and Lower $\mathrm{Zr} / \mathrm{Nb}$ ratio varying from 2 to 4 , support their kimberlite nature. The Seguela kimberlites show relatively high $\mathrm{Rb}, \mathrm{Ba}$, $\mathrm{Nb}$ and $\mathrm{La} / \mathrm{Yb}$ ratios compared to South Africa kimberlites, indicating that they derived from relatively low degrees of partial melting (Mitchell, 1986).

Slight depletions in $\mathrm{Ti}, \mathrm{Y}, \mathrm{Yb}, \mathrm{U}$ and Peraphs $\mathrm{Nb}$ and Ta may be a consequence of the dilution acquired during the accumulation of country rock or leaching, while the enrichment in $\mathrm{Rb}, \mathrm{Ba}, \mathrm{K}$, $\mathrm{La} \mathrm{Ce}$, and $\mathrm{Pb}$, may have resulted from alteration processes.

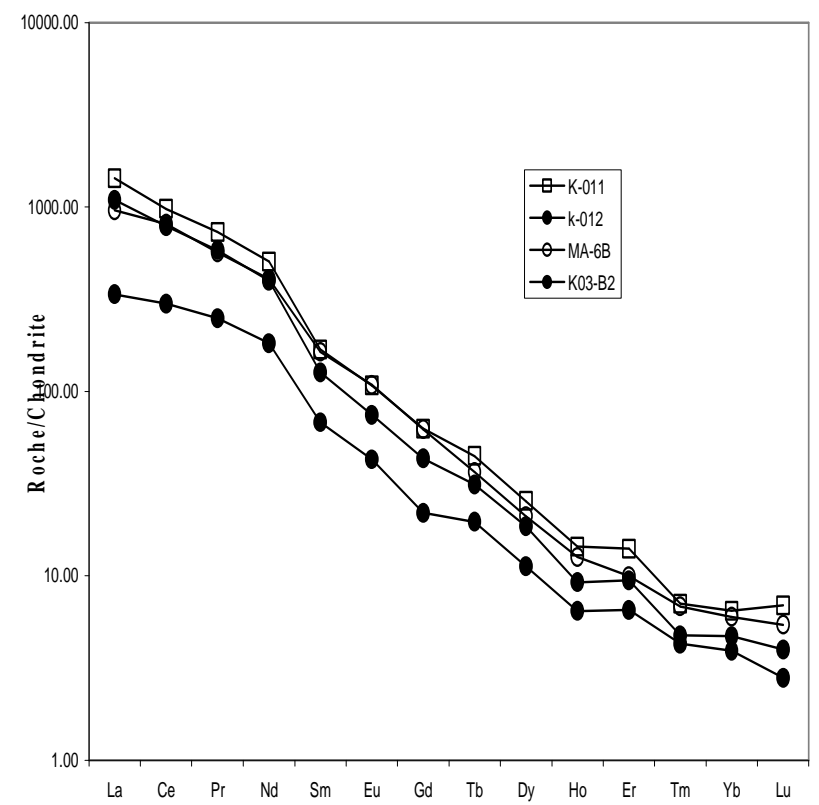

Figure 3: Selected chondrite-normalized REE patterns for Seguela pipe and dike samples (Sun and McDonough, 1989). 


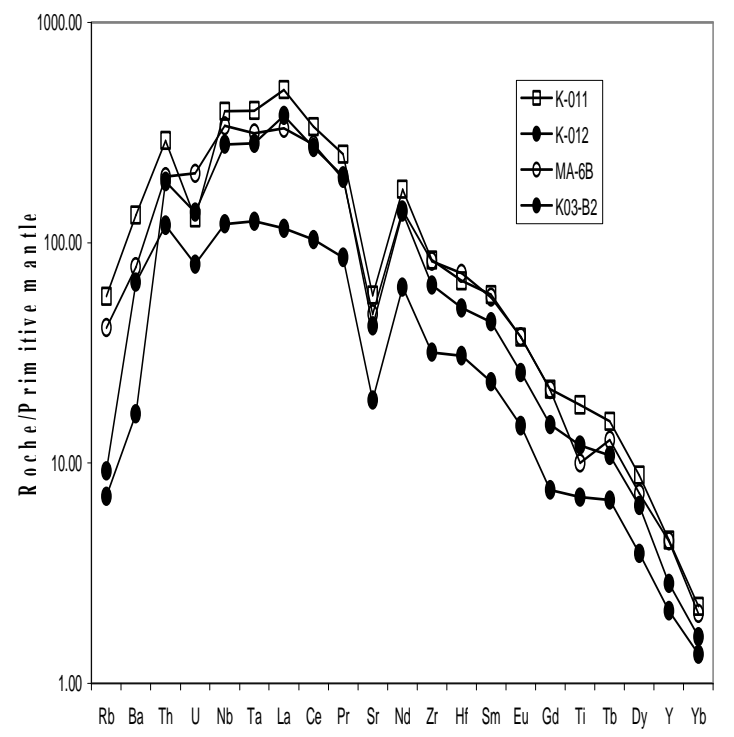

Figure 4: Average element abundance patterns normalized against primitive mantle for Seguela kimberlite and lamproite (Sun and McDonough, 1989).

\section{Discusion}

The sensitivity of incompatible element ratios to kimberlite alteration, including trace element ratios such as $\mathrm{Zr} / \mathrm{Nb}$ and $\mathrm{Nb} / \mathrm{La}$, which have petrogenetic significance (e.g., Weaver, 1991), can be evaluated from the Seguela kimberlites data. However, it should be stressed that the Seguela kimberlites are substantially more altered than any of the analysed Southern Africa material. The Seguela kimberlites show, on average, significant increase in the ratios $\mathrm{P}_{2} \mathrm{O}_{5} / \mathrm{Ce}, \mathrm{Ce} / \mathrm{Sr}, \mathrm{Ba} / \mathrm{Rb}$ (20-80), and $\mathrm{Nb} / \mathrm{La}$ that can be attributed to chemical alteration. $\mathrm{Zr} / \mathrm{Nb}$ ratio shows no discernable alteration-related trend. Ratios such as $\mathrm{Ce} / \mathrm{Sr}$ and $\mathrm{Ba} / \mathrm{Rb}$, which both increase sharply during the early stages of alteration, indicate that there is a distinctive pattern of alteration-related coupling between trace element ratios. These data together with overall abundances indicate that differential mobilisation of incompatible elements occurs during alterations

In West Africa there are some cretaceous kimberlite dikes and pipes in Sierra Leone according to $\mathrm{Rb}-\mathrm{Sr}$ and paleogenetic data (Taylor et al., 1994). The cretaceous age seems to be the more accurate and could be that of the Seguela kimberlites (Pouclet et al., 2004). New datas are proposed by Delor et al., (2004) U-Pb and Sm-Nd analysis from Guinea and Mauritania kimberlites. They were emplaced at 154-155 Ma which corresponds to Mid-jurassic age.

The study of diamond potential of Yakutian kimberlites in the petrochemical model (Vasilenko et al., 2002) showed that kimberlite varieties with $\mathrm{CaO} / \mathrm{MgO}$ ratio < 6 contain small amounts or lack diamonds. As the
$\mathrm{CaO} / \mathrm{MgO}$ (0.05-0.40 for Seuguela kimberlites) ratios decrease, diamond grade increases

Comparison of the average compositions of Seguela kimberlites and those of Yakutia suggests that the contents of $\mathrm{K}_{2} \mathrm{O}, \mathrm{Na}_{2} \mathrm{O}$ and $\mathrm{MgO}$ increase and the contents of $\mathrm{TiO}_{2}$ and $\mathrm{CaO}$ decrease with increasing diamond grade (Vasilenko et al., 2002).

\section{Conclusion}

Creataceous inferior Seguela kimberlites dikes and diatrems on the West African Craton are mostly diamond-bearing kimberlites with geochemical characteristics intermediate between southern Africa Group II kimberlites and Australia olivine lamproites.

\section{References}

Allialy, M.E., 2006. Pétrologie et géochimie des kimberlites diamantifères de Séguéla (Centre-Ouest de la Côte d'Ivoire). Thèse de Doctorat. Univ. Abidjan-Cocody, 162 p.

Bardet, M.G., Vachette, M., 1966. Détermination d'âges de kimberlites de l'ouest-africain et essai d'interprétation des datations des diverses venues diamantifères dans le monde, BRGM Rapport inédit DS 66 A 59, 15 p.

Clement, C.R., 1982. A comparative geological study of some major kimberlite pipes in the northern Cape and Orange Free State Unpubl. PhD. Thesis, Univ. Cape Town.

Delor, C., Lafon, J.M., Krymsky, R., Luais, B., Milesi, J.P., Phillips, D., Rombouts, L., 2004. Mid-Jurassic ages for West African kimberlites: first U-Pb and $\mathrm{Ar}-\mathrm{Ar}$ data. 20Th Colloquium on African Geology: Abstracts, Orleans, France., 2-7 June 2004-BRGM-436p.

Fieremans, M., Hertogen, J., \& Demaiffe, D., 1984. Petrology, geochemistry and strontium isotopic composition of the Mbuji-Mayi and Kundelungu kimberlites (RD.Congo). In Kimberlites I: Kimberlites and Related Rocks (ed. J. Kornprobst), pp. 107-120.

Grantham. D.R., and Allen, J.B., 1960. Kimberlites in Sierra Leone. Overseas Geol. Mineral Res. 8, 5-25.

Mitchell, R.H., 1986. Kimberlites Mineralogy geochemistry, and petrology. Plenum, New York, 442 pp.

Pouclet, A., Allialy, M.E., Yao, D.B., Botty, E., 2004. Découverte d'un diatrème de kimberlite diamantifère à Séguéla en Côte-d'Ivoire. C.R. Géosciences, 336, 9-17.

Sun, S.S., \& McDonough, W.F., 1989. Chemical and isotopic systematics of oceanic basalts: implications for mantle composition and processes, in: A.D. Saunders, M.J. Norry (Eds.), Magmatism in Ocean Basins, Geol. Soc. London Spec. Pub. N. 42, pp. 313-345.

Taylor, W.R., Tompkins, L.A., \& Hggerty, S.E., 1994. Comparative geochemistry of West African kimberlites: Evidence for micaceous kimberlites endmember of sublithospheric origin. Geochem. Como. Acta 58, pp. 40174037.

Vasilenko, V.B., Zinchuk, N.N., Krasavchikov, V.O., Kuznetsova, L.G., Khlestov, V.V., Volkova, N.I., 2002. Diamond potential estimation based on kimberlite major element chemistry. J. Geochem. Explor., 76, pp. 93-112.

Weaver, B.L., 1991. Trace element evidence for the origin of ocean-island basalts. Geology, 19, 123-126. 